\title{
Usefulness of clinical tests for assessing radicular and pseudoradicular components of pain in diagnosing sciatica - a pilot study
}

\author{
Przydatność testów klinicznych oceniających ból o charakterze korzeniowym \\ i pseudokorzeniowym w rozpoznaniu rwy kulszowej - badania pilotażowe
}

\section{Elżbieta Skorupska, Agata Bednarek, Magdalena Urna, Przemysław Lisiński, Magdalena Sobieska, Włodzimierz Samborski}

Department of Physiotherapy, Rheumatology and Rehabilitation of the Karol Marcinkowski University of Medical Sciences in Poznan Katedra Fizjoterapii, Reumatologii i Rehabilitacji Uniwersytetu Medycznego im. Karola Marcinkowskiego w Poznaniu

Key words: sciatica, functional tests, sacroiliac joint, Bragard's test.

Słowa kluczowe: rwa kulszowa, testy funkcjonalne, staw krzyżowo-biodrowy, test Bragarda.

\section{Sum mary}

Objectives: Varied and complicated aetiology of pain originating from the sacro-lumbar area with radiation to the lower limb is still causing disagreement and controversies around the issue of its diagnosis and treatment. Patients with low back pain radiating to the lower limb (sciatica) are clinically divided into two groups, radicular or pseudoradicular disorders. It is difficult to perform full diagnostics of these problems due to the lack of gold standards. The aim of the study was to evaluate which diagnostic tests may help in assessment of localization of pain and involvement of soft tissue in the pain pathomechanism.

Material and methods: Fifty patients with sciatica were checked using Lasegue's test, crossed straight leg raising test (xSLR), Bragard's test, and five sacroiliac joint (SIJ) tests: Yeoman manoeuvre, Patrick's test, Gaenslen's manoeuvre, Gillet test (Stork test), and standing flexion test.

Results: The results of Lasegue's test and Bragard's procedure showed a statistically significant correlation. Bragard's procedure was not confirmed for the patients with a bulging disc. Crossed SLR test was confirmed only in patients with hernia. In all patients with $\times S L R$ positive test result for the Bragard's procedure was confirmed. A positive result for at least one SI test was proven in $98 \%$ of patients, and four or five tests were confirmed in $20 \%$ of patients.

Conclusions: Simultaneous use of Lasegue's test and Bragard's procedure seems to be advisable but is not enough to prove sciatica as a cause of radicular pain. Patients with sciatica related to a bulging

\section{Streszczenie}

Cel pracy: Zróżnicowana i złożona etiologia bólu z okolicy lędźwiowo-krzyżowej z promieniowaniem do kończyny dolnej wzbudza ciągte spory i kontrowersje wokół kwestii diagnozowania i leczenia tej grupy chorych. Pacjenci, u których występuje ból odcinka lędźwiowo-krzyżowego pleców z promieniowaniem do kończyny dolnej, są dzieleni na tych, u których dolegliwości mają charakter korzeniowy i pseudokorzeniowy. Brak jednoznacznych kryteriów różnicujących te dwa komponenty bólu utrudnia ustalenie pochodzenia tych objawów. Celem pracy było zbadanie, które testy diagnostyczne mogą być przydatne w ocenie lokalizacji bólu i udziału tkanek miękkich w patomechanizmie rwy kulszowej.

Materiał i metody: Badaniu poddano 50 chorych, u których stwierdzono objawy rwy kulszowej i przeprowadzono test Lasegue'a, skrzyżowany test Lasegue'a (xSLR), test Bragarda oraz pięć testów oceniających stawy krzyżowo-biodrowe (sacroiliac joints - SI): test Yeomana, test Patricka, test Menela, test wypchnięcia i test kolców.

Wyniki: Wyniki testu Lasegue'a i testu Bragarda wykazywały istotną korelację u pacjentów z przepukliną krążka. U wszystkich pacjentów ze zmianami degeneracyjnymi krążka międzykręgowego (disc bulging) wynik testu Bragarda był negatywny. Skrzyżowany objaw Lasegue'a był dodatni tylko u pacjentów z przepukliną jądra miażdżystego. U wszystkich pacjentów, u których dodatni był wynik skrzyżowanego testu Lasegue'a, także wyniki testu Bragarda były dodatnie. Ponadto u $98 \%$ badanych dodatni był przynajmniej jeden z pięciu testów oceniających staw krzyżowo-biodrowy, wynik dla czterech pozytywnych testów stwierdzono u 20\% badanych.

\section{Address for correspondence}

dr n. med. Elżbieta Skorupska, Department of Physiotherapy, Rheumatology and Rehabilitation of the Karol Marcinkowski University of Medical Sciences, Fredry 10, 61-701 Poznań, e-mail: elzbieta.skorupska@interia.pl

Submitted: 24.04 .2013 
disc in a chronic state should be checked for the frequency of involvement of the sacroiliac joint.

\section{Introduction}

Pain in the lumbosacral region that radiates to the lower limb is divided into radicular and pseudoradicular pain [1]. Their differentiation and complex aetiology give rise to diagnostic disputes and controversies owing to the lack of unequivocally defined differentiating criteria. This causes doubts that arise when interpreting findings presented in reports touching on the subjects of diagnostics and therapy. Some authors have suggested that the majority of patients have mixed pain syndromes $[1,2]$.

The most common cause of radicular pain in the lower extremity is sciatica. Its aetiology emphasises nerve compression and associated inflammation, most often as a result of herniation of the nucleus pulposus of an intervertebral disc, vertebral canal stenosis, spondylolisthesis or a tumour [3]. Degenerative changes that occur in discs are considered to be the most important factor in the pathophysiology of lumbosacral spine pain radiating down to the lower extremity. Diagnostic techniques make it possible to obtain images of the abovementioned pathologies; therefore a diagnostic process that consists of assessing clinical symptoms of sciatica confirmed by neurophysiological tests and MRI (magnetic resonance imaging) raises the least doubts [4]. Despite the fact that in the vast majority of patients some of the described changes correlate strongly with pain experienced in the lower extremity (but not with lumbosacral pain), the results of MRI scans raise doubts with regard to the relation between the frequency of abnormal disc findings and their correlation with experienced pain [5]. MRI confirms the presence of pathological lesions in the discs of $38 \%$ of asymptomatic subjects. According to Takashasi or Kelly, compression of the nerve roots alone results in a loss of function rather than in pain [6]. Reports may also be found in the literature that emphasise the significance of inflammation in experiencing pain along the sciatic nerve in patients with pathological lesions in their intervertebral discs. The possibility that some patients may have so-called mixed pain syndromes should also be considered. Nerve inflammation and irritation may also affect soft tissues innervated by that nerve, for example the ischiocrural muscles or the sacroiliac joint [7]. Other causes of pain have not as yet been subjected to sufficient analysis on account of the scarcity of reliable studies in the absence of unequivocal MRI findings [3]. There are
Wnioski: Wyniki badania pozwalają stwierdzić, że przeprowadzanie jednocześnie testów Lasegue’a i Bragarda jest uzasadnione, ale niewystarczające do potwierdzenia korzeniowego charakteru bólu rwy kulszowej. Pacjenci, u których przewlekle występują objawy rwy kulszowej wiążące się z uwypukleniem krążka, powinni być również ocenieni pod kątem zajęcia stawów krzyżowo-biodrowych.

reports that state that patients with confirmed disc lesions or stenosis were observed to have symptoms simulating genuine neurological changes [8]. So-called sciaticalike symptoms (pseudo-sciatica symptoms) with a clinical picture similar to that of sciatica, where the sacroiliac joint (SI) is the potential source of complaints, should also be considered [3]. Demonstrating that dysfunction of this joint is the source of the pain is, however, difficult. Despite the availability of a large number of tests to confirm this joint as the source of pain, none have been approved as having sufficient sensitivity and specificity [9]. Imaging techniques are only capable of detecting a narrowing of the articular space or symptoms of inflammation within the SI joint [9]. The only sensitive diagnostic test for sciatica is the straight leg raise test, i.e. the Lasegue test (SLR); however, the test is flawed by low specificity and the absence of standards for its performance or interpretation [10]. According to some, a negative result has greater value for diagnosing pain than a positive finding [10]. The only undisputed feature is the usefulness of the test for establishing a diagnosis in patients with disc-related sciatica, particularly in cases with a herniated nucleus pulposus $[11,12]$. It has been suggested that performing the Lasegue test in combination with the Bragard test, which involves passive dorsiflexion of the foot while the lower limb remains elevated below the level at which the patient begins to feel pain, carries a higher probability of confirming a radicular source of pain $[10,13]$. Tarsal joint flexion produces pain along the course of the sciatic nerve. The role, sensitivity and specificity of other tests remain unclear [11]. In the presented paper, the authors attempted to evaluate which diagnostic tests used to assess involvement of the sacroiliac joint and surrounding soft tissues in the pain mechanism and, possibly, which combination of tests could help achieve higher precision in diagnosing pain.

\section{Material and methods}

The study involved 50 patients (19 females and 31 males) with acute and chronic sciatica. The mean age of the patients was $49.2 \pm 9.5$ years. The participants had been patients of the Department of Rehabilitation of the Karol Marcinkowski University of Medical Sciences in Poznań in the period from September 2007 to October 2008 (Table I). The inclusion criteria were: a diagnosis of intervertebral disc dis- 
Table I. A summary of the demographic profile of the tested group with division by type of disc degeneration

\begin{tabular}{|lccc|}
\hline & Study group & Hernia & Degenerative changes in the form of disc bulging \\
\hline Number of patients $(n)$ & 50 & 26 & 24 \\
\hline Males $(n)$ & 31 & 16 & 15 \\
\hline Females $(n)$ & 19 & 10 & 9 \\
\hline Age (in years) & $49.2(9.5)$ & $50.2(9.2)$ & $48.0(9.8)$ \\
\hline
\end{tabular}

Values expressed as mean (SD)

order confirmed by MRI, radiating pain consistent with the course of the sciatic nerve and a positive Lasegue test result. A specialist assessed each patient's radicular pain based on past history, neurological examination, lumbosacral spine X-ray and MRI. Exclusion criteria included: pain other than that caused by intervertebral disc disorder, presence of other neurological diseases or diabetes, a past history of spinal or lower limb injury or surgical intervention. Permission to conduct the study was granted by the Bioethics Committee of the Karol Marcinkowski University of Medical Sciences in Poznań. All of the patients gave written informed consent to participate in the study.

All of the patients included in the study had been diagnosed with discogenic sciatica, confirmed by MRI. Initially, patients were divided into 3 subgroups: subjects with acute pain (duration of up to 6 weeks), with subacute pain (present for more than 6 weeks, but less than 3 months) and with chronic pain (over 3 months' duration). Based on the absence of differences between the first and second group on preliminary examination, a decision was made to combine them and their results were compared to the results obtained in the group of patients with chronic pain. Patients rated the intensity of their pain on a visual analogue scale (VAS). Next, an experienced physiotherapist,

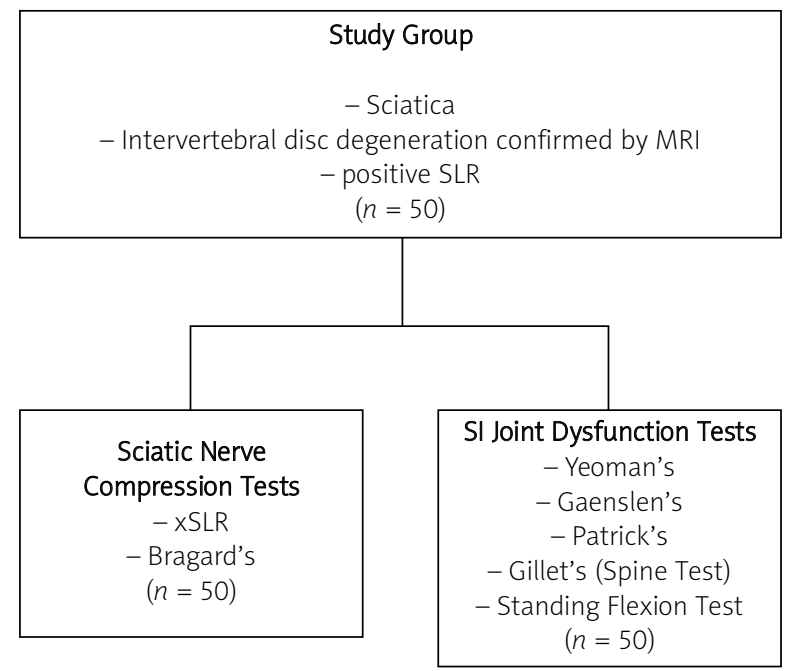

Fig. 1. Diagram of tests performed on total group. who was blinded to the location of the lesion, performed three radiculopathy tests - SLR, XSLR and the Bragard test - and five sacroiliac joint tests - Yeoman's test, Patrick's test, Gaenslen's test, the standing flexion test and the spine test (Gillet's test) (Fig. 1).

The main objective of the study was to examine the suggested correlation between the findings of the SLR test combined with the Bragard test and of the XSLR test combined with the Bragard test in subgroups depending on the type of intervertebral disc disorder. Statistical analysis was performed using the $\chi^{2}$ test and the ANOVA test. An additional objective was to assess the rate of positive SLR test results in patients with intervertebral disc pathology and to establish which combinations of tests are performed on patients with intervertebral disc disorder. These calculations were performed using the ANOVA test. StatSoft Statistica 7.0 software was used to analyse data.

\section{Results}

\section{Study group profile}

Among the 50 subjects with diagnosed sciatica, 56\% $(n=28)$ had acute (i.e. short-term) symptoms; of these, $42 \%$

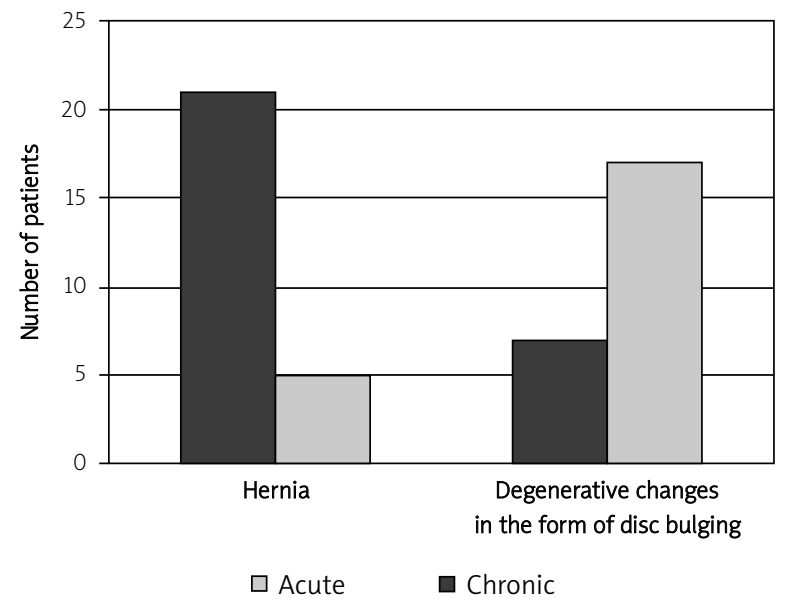

Fig. 2. Patients in groups according to duration of the disease and type of disc degeneration. 


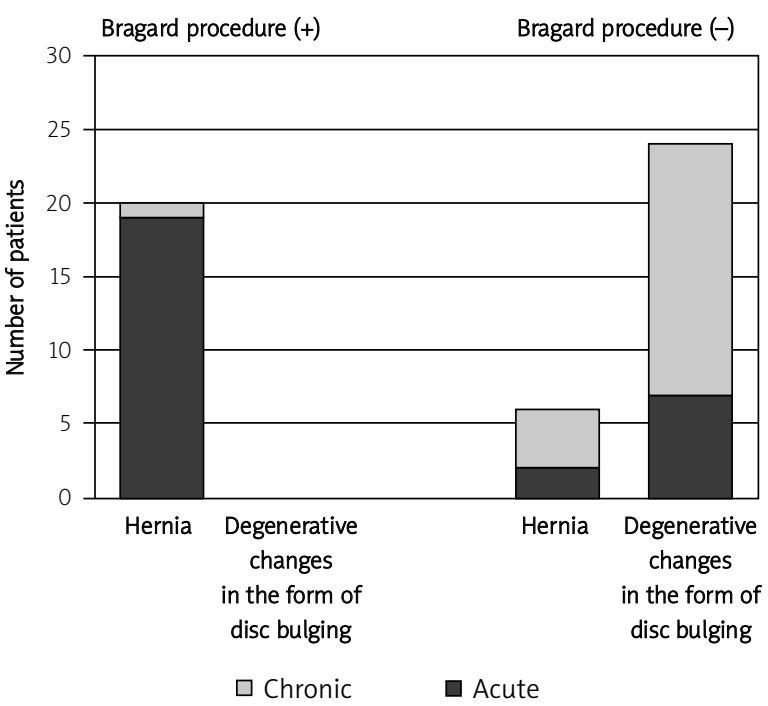

Fig. 3. Division of the study group according to the result of Bragard's test.

$(n=21)$ had disc herniation and $14 \%(n=7)$ had degenerative changes in the form of disc bulging. Chronic symptoms were experienced by $44 \%$ of patients $(n=22)$, of whom $10 \%(n=5)$ had a herniated disc and $34 \%$ $(n=17)$ had degenerative changes (Fig. 2).
Differences in the intensity of pain measured using the VAS scale (0-10) between the study groups were not statistically significant; a tendency towards a reduction in the intensity of pain over time was noted. The mean level of pain experienced by patients in the acute phase was $7.21 \pm 1.98$ and $5.36 \pm 1.2$ for patients in the chronic phase.

\section{Radiculopathy test results}

The results of both tests, i.e. the SLR and the Bragard tests, were positive in $40 \%$ of patients in the study group $(n=50)$. Depending on the nature of their disorder, it was established that none of the patients with degenerative changes in the form of disc bulging had a positive Bragard test whereas this test was positive in 20 out of 26 patients in the group with disc herniation. The distribution of Bragard test results according to the type of pathology and duration of pain is presented in Fig. 3.

Using Spearman's test, a significant correlation was determined between test results $(r=0.78)$. Differences between the subgroups according to duration and the nature of the pathology were analysed using the ANOVA test and the Wilks lambda test: $\lambda=0.70057 ; F(2.45)=$ $=9.6168 ; p=0.00033$ (Fig. 4).

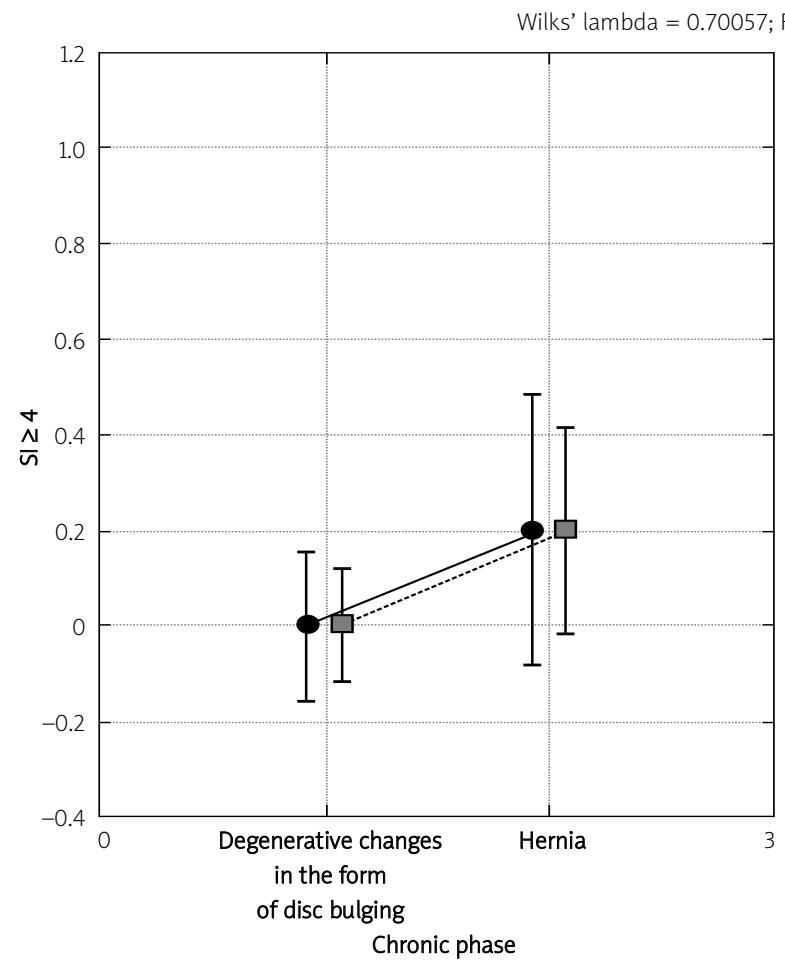

$\overline{\underline{\underline{9}} \times S L R}$
45) $=9.6168 ; p=0.00033$

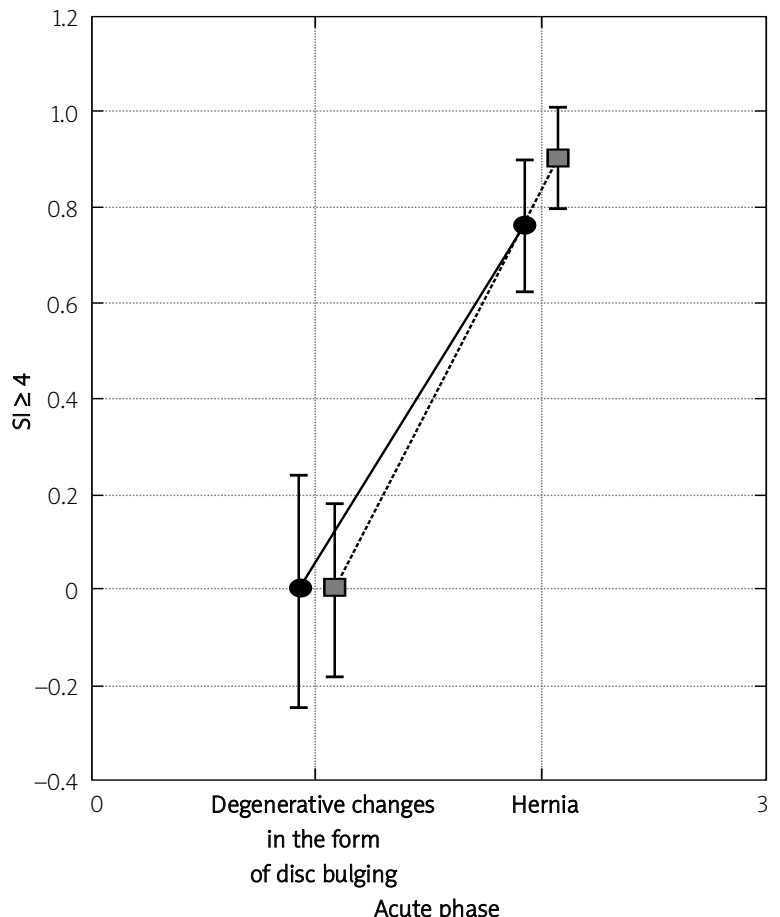

호- Bragard's test

Fig. 4. Results of xSLR and Bragard tests in studied patients divided according to duration of pain and type of disc degeneration. 
Among the studied subjects, only patients with a herniated disc had a positive XSLR test (17 out of $26,34 \%$ of the total study group). All of the patients with a positive Bragard test had a positive XSLR test result (a significant correlation was found between the conducted tests, Spearman's coefficient $r=1$ ).

\section{Results of tests confirming sacroiliac joint involvement}

Among the whole study group, $98 \%$ of patients tested positive for at least one test confirming a sacroiliac joint disorder (Patrick's test was positive in $40 \%$ of study subjects, Gaenslen's test in 44\%, Yeoman's test in 48\%, the standing flexion test in 38\% and the spine test in 24\%). Twenty percent of patients had positive results of at least 4 out of the 5 conducted tests, including 6 patients out of 21 with chronic disc herniation and 4 out of 17 subjects with acute herniated discs. The study confirmed a statistically higher probability of SI joint involvement in patients in the chronic phase. The results are presented in Fig. 5.

\section{Discussion}

The main cause of pain radiating along the posterior surface of the lower limb is commonly attributed to compression of the sciatic nerve. The inclusion criterion for this study was a diagnosis of sciatica based on clinical symptoms, including the SLR test - positive in all patients - and confirmed by MRI imaging. As mentioned in the introduction, the specificity of the SLR test is low; therefore the Bragard test was performed in addition to SLR. Both tests were positive in $40 \%$ of subjects. Depending on symptom duration, it was determined that a negative Bragard test is characteristic for the group of patients with chronic changes in the form of disc bulging. On the other hand, the group with a positive Bragard test consisted mainly of patients in the acute phase, with disc herniation confirmed by MRI. A significant correlation was seen between positive SLR and Bragard test results $(r=0.879)$. A correlation of $r=1$ was found for the $\mathrm{xSLR}$ test performed in combination with the Bragard test. This association was only determined for patients in the acute phase because the number of patients with chronic herniation was too small.

Various authors have indicated that typical patterns of pain corresponding to disc protrusion at segment L5-S1 may occur concurrently with sacroiliac joint dysfunction [3]. Confirmation of intervertebral disc pathology using MRI imaging does not exclude this phenomenon. Subjects in the study group had a verified positive result for at least one of the tests used to confirm SI joint pain. According to the literature, a more reliable confirmation of SI joint dysfunction is only possible with $3-5$ positive test results [14].

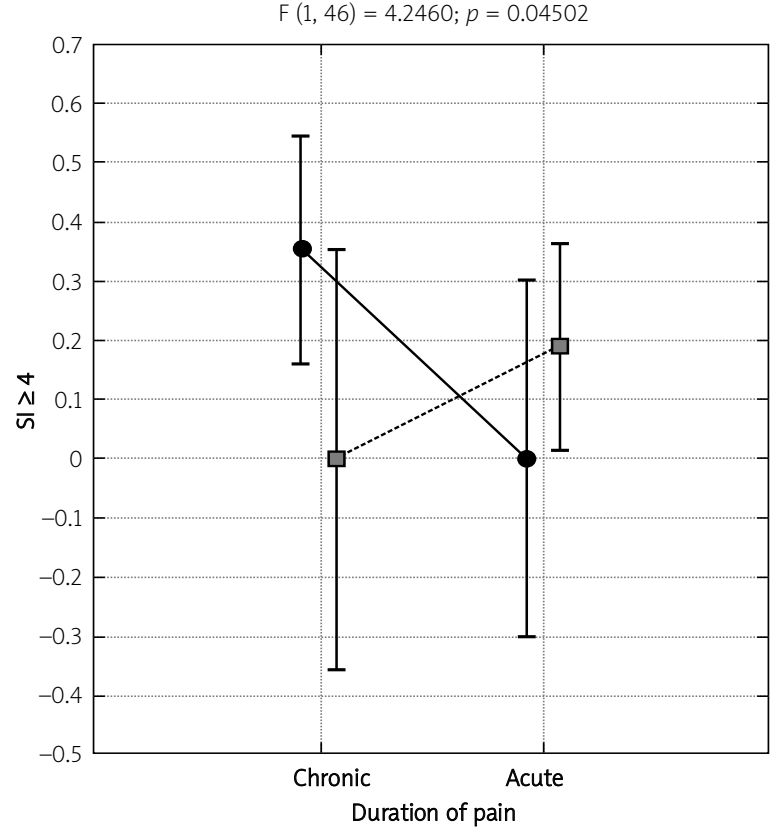

호 Degenerative changes in the form of disc bulging
栭- Hernia

Fig. 5. Results of tests confirming SIJ involvement in patients divided according to duration of pain and type of disc degeneration.

An analysis of the study group with respect to the duration of symptoms and disc pathology produced the first discernible associations (Fig. 5). For patients with disc herniation, test results were positive only in patients in the acute phase of the disease; Yeoman's test was the only test that gave a positive result in 2 individuals in the chronic phase. In patients with no evidence of herniation, the positive results of all the tests were verified in the group in the chronic phase. There was an evident tendency for SI joint pain to occur in the acute phase in cases of disc herniation or in patients in the chronic phase with degenerative changes in the form of disc bulging. In the study group, 4-5 positive test results were obtained mainly in individuals with chronic discopathy $(n=6,12 \%$ of all examined subjects), which would indicate an association with the duration of the pathological process. However, 4-5 positive sacroiliac joint dysfunction test results were also verified in patients with disc herniation, albeit only in subjects in the acute phase (8\%). In view of the fact that the innervation of the SI joint (levels L4-L5 and S1-S2) corresponds with the level of innervation for the sciatic nerve (from $L 4$ to S3), irritation of this joint may be present despite a primary, correct diagnosis of sciatica. Pain may also be transmitted somatically from pain receptors, for example from an intervertebral disc or the sciatic nerve $[15,16]$. It is difficult, however, to establish the cause of the projected 
pain component in patients in the chronic phase, who only have confirmed disc bulging. It may be caused by assuming a compensatory protective posture in the acute phase, all the more so since Vleeming observed that patients with $\mathrm{SI}$ joint pathology experience a recurrent pattern of muscular imbalance [17]. Positive results obtained in more than three SI joint tests make it possible to put forward the hypothesis that mixed pain may occur in the study group in patients with discogenic radicular pain.

\section{Conclusions}

To sum up, it is not possible to reject the hypothesis that the SLR and Bragard tests, applied at the same time, are a good direction to take for the diagnostic process of patients in the acute phase, with disc herniation confirmed by MRI imaging; nonetheless, this is not a solution that would sufficiently confirm the radicular nature of the pain in all patients with disc-related sciatica. Patients with chronic sciatica may experience a pain component stemming from the sacroiliac joint. The direction in which the diagnostic procedures presented in this report are moving requires further research involving a larger group of patients.

Authors declare no conflict of interests.

The work was supported by research project NCBN NN4042683 39.

\section{References}

1. Baron R, Binder A. How neuropathic is sciatica? The mixed pain concept. Orthopade 2004; 33: 568-575.

2. Sembrano JN, Polly DW Jr. How often is low back pain not coming from the back? Spine (Phila Pa 1976) 2009; 34: E27-E32.

3. Buijs E, Visser L, Groen G. Sciatica and the sacroiliac joint: a forgotten concept. Br J Anaesth 2007; 99: 713-716.

4. Stafford MA, Peng P, Hill DA. Sciatica: a review of history, epidemiology, pathogenesis, and the role of epidural steroid injection in management. Br J Anaesth 2007; 99: 461-473.

5. Porchet F, Wietlisbach V, Burnand B, et al. Relationship between severity of lumbar disc disease and disability scores in sciatica patients. Neurosurgery 2002; 50: 1253-1259.

6. Takahashi K, Shima I, Porter RW. Nerve root pressure in lumbar disc herniation. Spine (Phila Pa 1976)1999; 24: 2003-2006.

7. McCarron RF, Wimpee MW, Hudkins PG, Laros GS. The inflammatory effects of nucleus pulposus. A possible element in the pathogenesis of low back pain. Spine (Phila Pa 1976) 1987; 12 760-764.

8. Boss N, Semmer N, Elfering E, et al. Natural history of individuals with asymptomatic disc abnormalities in magnetic resonance imaging. Spine (Phila Pa 1976) 2000; 25: 1484-1492.

9. van der Wurf P, Bujis EJ, Groen GJ. A multitest regimen of pain provocation tests as an aid to reduse unnecessary minimal invasive sacroiliac joint procedures. Arch Phys Med Rehabil 2006; 87: $10-14$.
10. Rebain R, Baxter GD, McDonough S. A systematic review of the passive straight leg raising test as a diagnostics aid for low back pain. Spine (Phila Pa 1976) 2002; 27: E388-E395.

11. Rubinstein SM, van Tulder M. A best-evidence review of diagnostic procedures for neck and low-back pain. Best Pract Res Clin Rheumatol 2008; 22: 471-482.

12. Majlesi J, Togay H, Ünalan H, Toprak S. The sensitivity and specificity of the slump and straight leg raising tests in patients with lumbar disc herniation. J Clin Rheum 2008; 14: 87-91.

13. Rolke R. Pseudoradicular and radicular low-back pain -A disease continuum Rather than different entities? Reply to the letters by Leffler and Hansson and by Van Boxem et al. Pain 2008; 135 : 314-316.

14. Bush K, Cowan N, Katz DE, Gishen P. The natural history of sciatica associated with disc pathology. A prospective study with clinical and independent radiologic follow-up. Spine (Phila Pa 1976) 1992; 17: 1205-1211.

15. Fortin JD, Dwyer AP, West S, Pier J. Sacroiliac joint: pain referral maps upon applying a new injection/arthrography technique. Part I: Asymptomatic volunteers. Spine (Phila Pa 1976) 1994; 19 : 1475-1482.

16. Slippman CW, Whyte II WS, Chow DW, et al. Sacroiliac joint syndrome. Pain Physician 2001; 4: 143-152.

17. Vleeming A, Van Wingerden JP, Snijders CJ, et al. Load application to the sacrotuberous ligament: influences on sacroiliac joint mechanics. Clin Biomech 1989; 4: 204-209. 